\title{
INTANGIBLE ASPECTS ATTACHED TO THE MAHĀKĀLA WORSHIP IN HINDU AND BUDDHIST TEXT
}

\author{
DR. POONAM R. L. RANA
}

\begin{abstract}
Mahäkāla is the God of Time, Maya, Creation, Destruction and Power. He is a form of a Brahman Mahākāla that is affiliated with Lord Shiva. His abode is the cremation grounds. He has four arms and three eyes, and is often depicted to be sitting on five corpses. In his arms he wields a trident, drum, sword and hammer. He rubs ashes, from the cremation ground, on himself. He is surrounded by vultures and jackals. His consort is Käli. Mahākāla and Kāli are the personification of time and destruction.
\end{abstract}

\section{Etymology of the name Mahākāla}

The word Mahākāla is a Sanskrit word. Mahā means 'Great' and Kāla refers to 'Time or Death' hence translating Mahākāla to mean "Beyond time or Death" (Mookerjee, 1988. NY). The Tibetan Buddhist calls Mahākāla 'Nagpo Chenpo' which translates into 'Great Black One' and also 'Ganpo' which means 'The Protector'.

\section{The iconographic features of Mahākāla in Hindu text}

Shaktisamgama Tantra: The male spouse of Mahākāli is the outwardly frightening Mahākāla (Great Time), whose is often portrayed by meditatative image (dhyāna) of mantra, yantra and meditation. In the Shaktisamgama tantra, the mantra of Mahākāla is 'Hum Hum Mahākāla praside praside Hrim Hrim Svaha'. The meaning of the mantra is that Kālikā, is the Virāt meter, the bija of the mantra is Hum, the shakti is Hrim and the linchpin is Svaha.

Mahākāla has four arms and three eyes, and is of the brilliance of $10,000,000$ black fires of dissolution, dwells in the midst of eight cremation grounds, is adorned with eight skulls, seated on five corpses, holding a trident, a damaru, a sword and a kharpa in his hands.

With a beautiful body adorned with ashes from the cremation ground, standing on various corpses he dallies with Kālikā, fondling her and making love with her and fiercely kissing her, surrounded by numbers of 


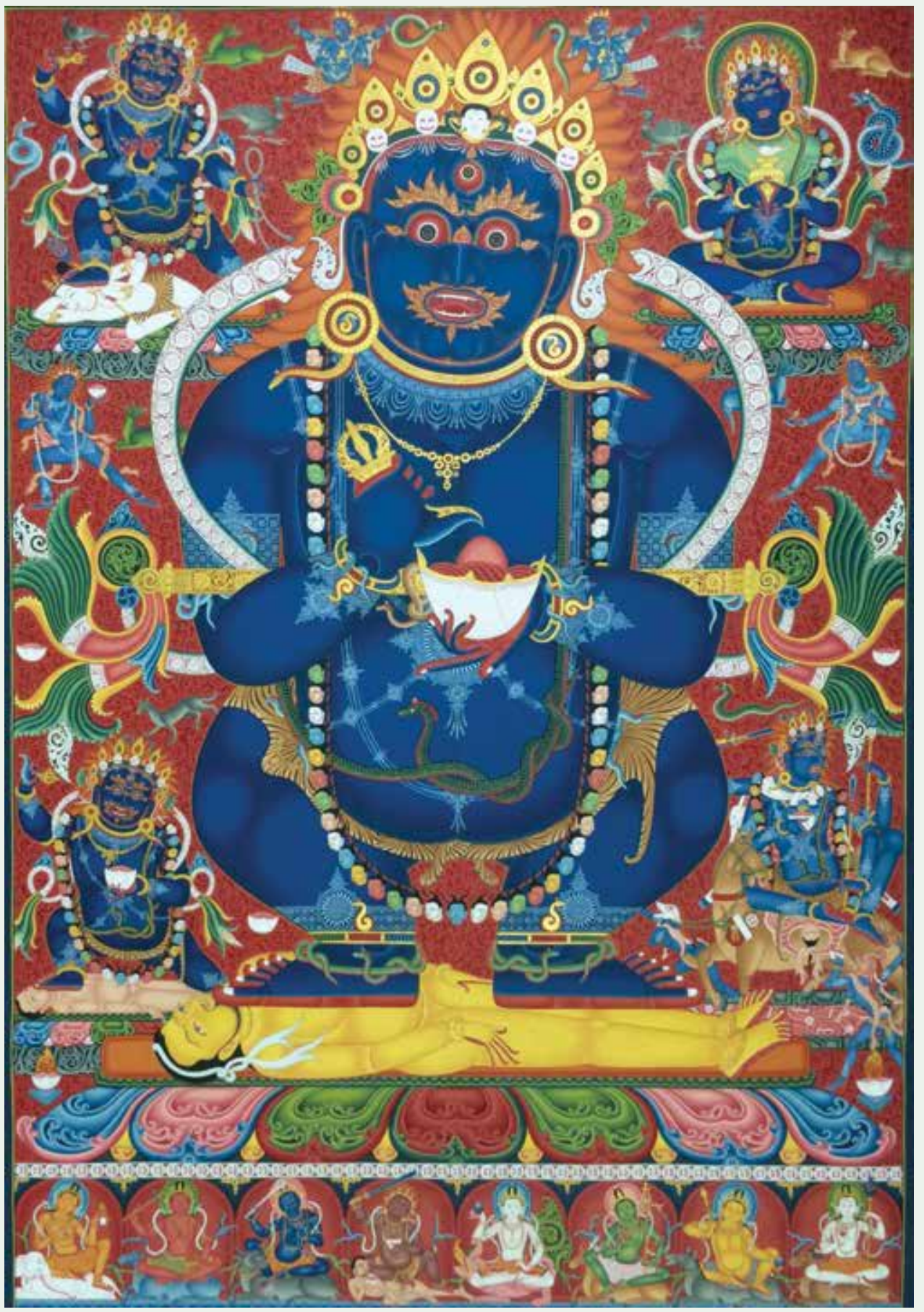

Mahākāla, 15th century, $97 \mathrm{~cm} \times 66.5 \mathrm{~cm}$. 
loudly shrieking vultures and jackals, adorned with a heap of braided hair, in a deserted place.

Kālikā is void, ornamented with skulls, with a sweet and charming face, in the midst of that five-fold love-yantra. Her yoni is the wheel of time (kālachakra). (Shaktisamgama Tantra)

\section{Description}

\section{Shaktisamgama Tantra:}

Shaktisamgama Tantra, the spouse of Kāli is extremely frightening. Mahākāla has four arms, three eyes and is of the brilliance of ten million black fires of dissolution. He dwells in the midst of eight cremation grounds. He is adorned with eight skulls, seated on five corpses, holds a trident, a drum, a sword and a scythe in his hands.

He is adorned with ashes from the cremation ground and surrounded by numbers of loudly shrieking vultures and jackals. Among his side is his consort Kāli and they both represent the flow of time. Both Mahākāla and Kāli/Mahākāli represent the ultimate destructive power of Brahman and they are not bounded by any rules or regulations.

When Mahākāla and Mahākāli are together they have the power to dissolve even time and space into themselves and exist as a void at the dissolution of the universe. They are responsible for the dissolution of the universe at the end of Kalpa. They are also responsible for annihilating great evils and great demons when other Gods, Devas and even Trimurtis (trinity) fail to do so.

Mahākāla and Kāli annihilate men, women, children, animals, the world and the entire universe without mercy because they are Kāla or the personification of Time, and Time is not bound by anything and Time does not show mercy, nor does it wait for anything or anyone.

Mahāpasupat Sastra: "Kāla" refers to "Time" and also "death". Usually kāla is used as a synonym for "mrityu" (Yama) the god of death. Lord Șhiva is the death of even death - we have a legendary example of Bhakta Mārkandēya who was born with a limited lifespan but because he was devoted to Mahādēva when Yama tried to seize his life forces, Mahādēva rescued him from Yama and even killed Yama who paradoxically is hailed by the name of 'kāla'.

Therefore Bhagawān Șhiva is the kāla of kāla hence the name "Mahākāla". However, scriptures do not use the term, "Mahākāla" to always refer to Shiva in his aspect of Time or Death, but mostly the term Kāla is used to describe him alone and only selectively it is used to describe Yama.

Mahākāla is beyond the three divisions of Time, and he is the creator of Time and he is the withdrawer of Time as well. Time (kāla) is again of two types, viz. kṣhara and akșhara; 
the former one is withdrawn during cosmic dissolution, the latter which represents 'eternal-time' is nothing but another synonym to call "brahman". Both kinds of Time are Mahādeva alone. This second 'time' which is the supreme and imperishable time is Brahman (Mahākāla's nirguna aspect, Shvetashvatara Upanishad).

Veda: Mahākāla is regarded as Bhagawan or self-originated, nothing generates it. It is without origin. In contrast, kāla is always moving on (gatisheel), it can never be stopped. The name 'kāla' signifies both time and death. Kāla is responsible for the life and death of each human being. Kāla is the destroyer of all existence, carrying all organisms towards physical destruction. Qualities attached to time are responsible for all happiness and sorrow. These concerns are the domain of Jyotish astrology. (Parashara M. Brihat: 1994, New Delhi Sagar.)

Bhagavad Gita: In the Bhagavad Gita 11.32, Krishna takes on the form of kāla, the destroyer, announcing to Arjuna that all the warriors on both sides will be killed, apart from the Pandavas:

'कालोऽस्मिलोकक्षयकृत प्रवृद्धो लोकान् समाहर्तम् इह प्रवृत्तः ।'

This verse means: "Time (kāla) I am the Mahākāla, the great destroyer of the worlds, and I have come here to destroy all people." (Bhagavad Gita 11.32 )
In the Book Hindu Temple Vol. II mentions of Shiva as Mahākāla shares the name and features of Kirtimukha (Kāla). The Lingayat Legend views that Shiva, Sankara, Sarabbha seized Narashima who had become very proud after having killed Hiranyakasyapa; the brother of Simhika, who is Rahu's mother; and out of Narashimas, severed head Shiva made Kirtimukha.

The legends in Puranas says Kirtimukha should be represented at the entrances of Shiva temples and should be worshipped on entering the temple.

The image of Shiva in his terrific or ugra form or aspect is termed as Aghora, Bhavava and Mahākāla are depicted with bulging eyes, inflated cheeks and tusks etc. (Kramrisch, 1976, New Delhi)

Mahābharata and Haribansa Purana: Lord Krishna did not kill Bānāsura, only defeated him and cut all of his one thousand arms but four. It's interesting what happened to Bānāsura. After the battle, Nandi suggested him to dance for Shiva. So in this amputated state he did Tāndava for Shiva. After that Lord Shiva made him Mahākāla. It might have been a test for him, to see if he could still perform in this condition. The description of the dance is wonderful. He danced his eyebrows, produced different sounds, and all this while fully covered in blood. 


\section{Mahākāla in Sanatan Dharam}

In the Hindu religious text Mahākāla is regarded as the ultimate form of Lord Shiva, the destroyer of all elements. It is believed that there is nothing beyond him, no elements, no dimensions not even time. That is why he is called 'Mahā' meaning greater than time or 'Kāla'. Kāla is also known as time or death.

There is another meaning of Mahākāla that emphasizes the destructive aspect of time. Everything dies with time: "Time ripens the creatures, Time rots them. "Time" (kāla) is thus another name for Yama, the god of death. The name is associated with Shiva in his destructive aspect as Mahākāla and is extended to his consort, the goddess Kāli, or Mahākāli. (Mahabharata 1.1.188)

In Kālatantra, Mahākāla(i) is the patriarchal "God of Time". However, originally "he" was the Universal Great Mother, ruling "birth and death" (which is the foundation of time). Here we have restored her original power. Linguistically we have to call Her "Mahākāli", which is the feminine version. In order to remember the "coup" we keep calling Her "Mahākāla", though. The same we did with the "Kāla". It deals with time and death.

Mahākāla is referred to as bringer of death. In many parts of India and Nepal followers of Sanātana Dharam worship Mahākāla to ward away untimely death. In the region of Jharkhand, Odisha, and Northern Bengal they regard wild elephants as Mahākāla and worship them.

\section{The Hindu legends on Mahākāla}

In the Brahmā Purana on 'Shiva Mahākāla' there is this myth:

"Once all the creatures were created and their hunger satiated they began to reproduce. Soon there were too many of them. Brahmā could see that the cosmos was choked with too much life. He wondered where he had made an error.

Saraswati pointed out to him that he had forgotten to create death. For life to go on he realized death was essential. He created Mrityu, and ordered her to go and kill all creatures. Mrityu was horrified of the formidable task and fled.

Shiva found Mrityu crying in a desolate place. He consoled her and assured her that all those who would die would be reborn. So she would be mother even though she would be taking life away. Thus, it came to be that Death became not the end of life but a gateway to a new one. Mrityu took the form of Mahākali, devoured all life and Shiva became Mahākāla, the lord of time, the regenerator. Life became a wheel, rotated by Shiva an eternal cycle of births and rebirths.

\section{The famous Mahākāla temple in Kathmandu}

The three-storeyed temple of Mahākāl lies West of Tundikhel in Kathmandu, 


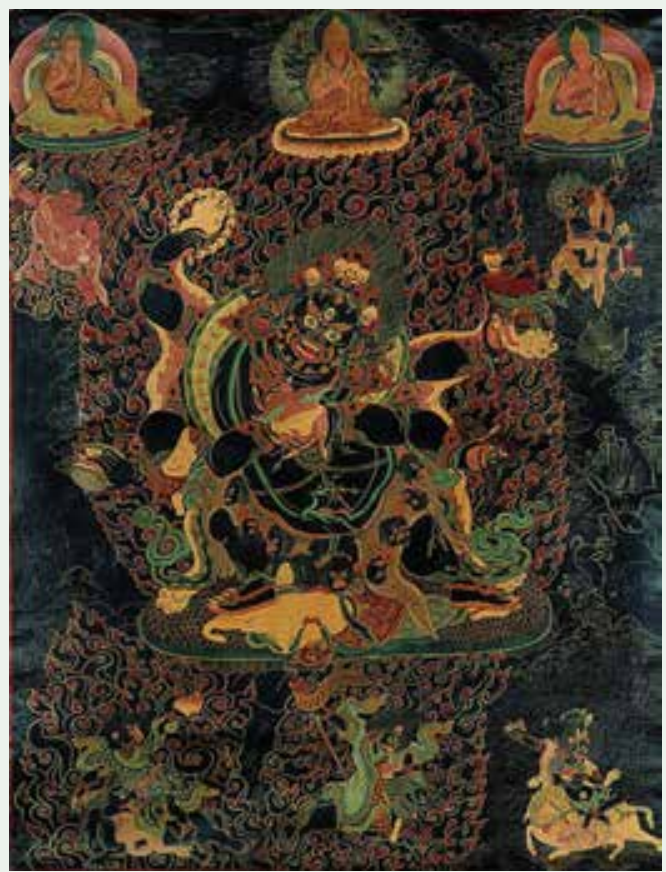

A form of Mahākāla

and houses a terrifying idol of the deity.

The idol is made of fine black stone and depicts the deity wearing a garland of human skulls and standing on a dead body with his mouth open, while the nose and ears are covered with metal leaflets. The temple is said to have been established by the King Gunakamadeva. The date is under contradiction.

The Legend: The legend goes that the temple was founded by a Tantric Guvaju. One day while he was rearing his goat at Tudhikhel he witnessed the Mahākāla flying across the sky towards China. He is believed to have called upon the King Gunakamadeva of Kantipur, where upon the two of them decided to build an idol so as to persuade Mahākāla to stay here permanently.

However, Mahākāla refused the request but agreed to visit the temple every Saturday. Thus, thousands of people visit the temple on Saturdays as it is believed that the deity himself is present there then.

\section{Mahākāla in the Buddhist text}

In the Tibetan text: "Mahākāla namo" in the Tibetan text it is said that Mahākāla means literally "the great black one" Namo means "hail" or "homage". Mahākāla symbolizes the wrathful aspect of the compassionate mind, transforming energies such as anger into a powerful compassionate force.

Mahākāla is a Dharmapāla, a protector of religious law. He is always depicted as an extremely fierce and terrifying deity. His purpose is to help in overcoming negative obstacles on the path to enlightenment. A compassionate wrathful deity, he appears evil, like a demon, but functions more like a guard dog, or guardian angel (Sergent). His aggression is necessary, for it allows him to demolish obstacles and negativities one faces on the path to enlightenment. Mahākāla is depicted in a variety of different ways, sometimes with six arms, other times with two. He is often brown skinned and associated in tankas with Penden Lhamo. 


\section{The Himalayan Resource}

The designation of 'Protector Deity' is common within the Buddhist and Bon religions of the Tibet and Himalayan regions. The term is one designation in a rather fluid yet elaborate set of religious hierarchies in the various pantheons.

There are two types of Protector Deity: worldly and beyond worldly. The latter is typically called wisdom or enlightened protector, meaning that they are beyond samsāra or worldly existence.

The Buddhist protector deity Mahākāla is a wrathful form of the primordial Buddha Vajradhara. In various other forms Mahākāla can be an emanation of Akshobhya Buddha or any number of other Buddhas.

The three main Anuttarayoga Tantra deities of Hevajra, Chakrasamvara and Guhyasamāja each have a specific Mahākāla associated with the particular tantra such as: Panjara Mahākāla - Panjarnata Tantra (Hevajra), Chaturmukha Mahākāla - Guhyasamāja Tantra and the Chaturbhuja Mahākāla associated with the various Chakrasamvara Tantras.

Worldly protectors are not enlightened and not considered completely trustworthy. There is a bias in Buddhism to treat all or almost all protectors coming from India to be wisdom protectors. The exception here are the Four Guardian Kings and what are considered the traditional Hindu Gods, often referred to in the Tantras as worldly gods, or protectors.

Numerous mountain gods and indigenous Tibetan and Himalayan deities have been incorporated into the Tantric Buddhist pantheon as worldly deities with the function of a protector. Their job is to safe-guard Buddhism in general, regions, specific monasteries or religious traditions or even a specific text as in the Nyingma Tradition.

\section{The Legend of the Origin of Mahākāla}

The compassion of the red Buddha Amitābha manifested as Avalokiteshvara who took a vow to forgo his own enlightenment until all the realms of samsāra had been emptied. This vow required a renewal of determination, and so with Amitābha's blessing, Avalokiteshvara next assumed a form with eleven heads and a thousand arms. Still he had been unable to benefit even a few beings.

Therefore after reflecting for one whole week, he determined that by assuming a wrathful form he would be able "to subdue the degenerate beings of this Age of Darkness."

He also saw that even beings who practiced Dharma were unable to escape from the Bardo realms (time between rebirths where beings may face great anxiety and terrifying 
experiences) and he thought that in wrathful form he could also protect them in that way.

Lastly, he thought that the beings in this Dark Age were poor and needy, experiencing only suffering after suffering, and that in wrathful form he could provide them an antidote to that suffering so that by simply making the wish (for protection) their needs could be met.

These three motives made his determination even greater than before and so from the heart of Noble Avalokiteshvara emerged a dark blue HUNG syllable that immediately became the Instantaneous Protector of Wisdom, Mahākāla.

\section{The Different forms of Mahākāla}

In the Buddhist texts there are 75 forms of Mahākāla in Tibetan Buddhism. Iconographically there may be fewer forms but textually there can be an infinite number. Some are as follows:

\section{Chaturbhuja Vajra Nata Mahākāla} (Tibetan: gon po chag shi pa, dor je nag po chen po. English The Great Black Vajra Lord with Four Hands) embracing the consort

From the Tradition of Arya Nāgarjuna. In Tibetan it is known as 'Chag shi pa' the chaturbhuja Mahākāla has four hands.

At the top center is the primordial Buddha Vajradhara. At the left are Vajrapāni, Ga Lotsawa and Padma

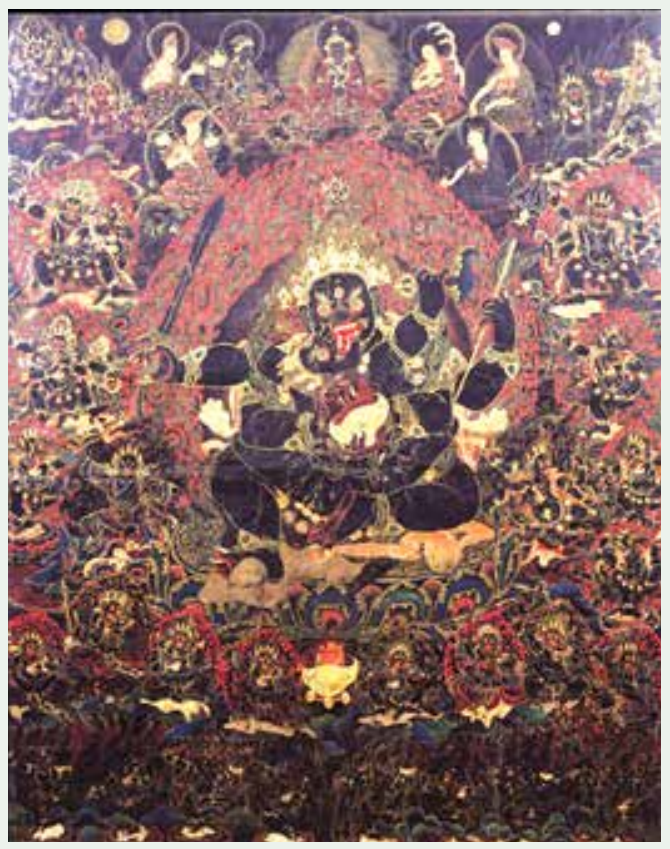

Chaturbhuja Mahākāla

Karpo (Pema Karpo). At the right are Nāgarjuna, Tsangpa Gyare and Kunzang Jalu.

Iconography: With one face and four hands, blue-black in color, Mahākāla glares ferociously with three large round eyes, bared fangs and orange hair flowing upward. He has four hands. The first pair of hands hold a fresh heart and the left a skull cup - held to the heart embracing the consort. The second right hand holds upraised a sword and in the left a katvanga staff with a trident point.

Ferocious in appearance the consort holds a skull cup in the left hand. Both are adorned with a tiara of skulls, bone and jewel ornaments, garlands of heads and green silk scarves. The Lord wears a tiger skin as a lower 
garment and the consort a girdle of finely strung bone ornaments. In a relaxed posture they are seated above a multi-coloured lotus, sun and red corpse seat surrounded by the flames of pristine awareness interspersed with the emanations of black dogs, birds and Garudas. ( Jeff Watt 9-2000 )

\section{Shadbhuja Mahākāla (Shangpa)}

Brought to Tibet by Khyungpo Naljor the founder of the Shangpa Kagyu School, this form of Mahākāla became popular in the Sakya, Kagyu and Jonang traditions and was later adopted into the Gelugpa School, becoming the principal protector.

There are other six-armed forms Mahākāla that are unrelated to this particular six-armed Shadbhuja Mahākāla.

Shadbhuja Mahākāla arises from the Eight-Chapter Mahākāla Tantra belonging to the Kriya classification. In general Mahākāla forms are wrathful emanations of Vajradhara Buddha. From among the different forms of Mahākāla only this Shadbhuja form is an emanation of Avalokiteshvara.

Shadbhuja has a number of different forms recognizable by a variation in body color, the addition of a consort, hand attributes and retinue figures.

The most popular being the wealth deity White Mahākāla practiced in all traditions of Tibetan Buddhism. Variations in appearance are found in

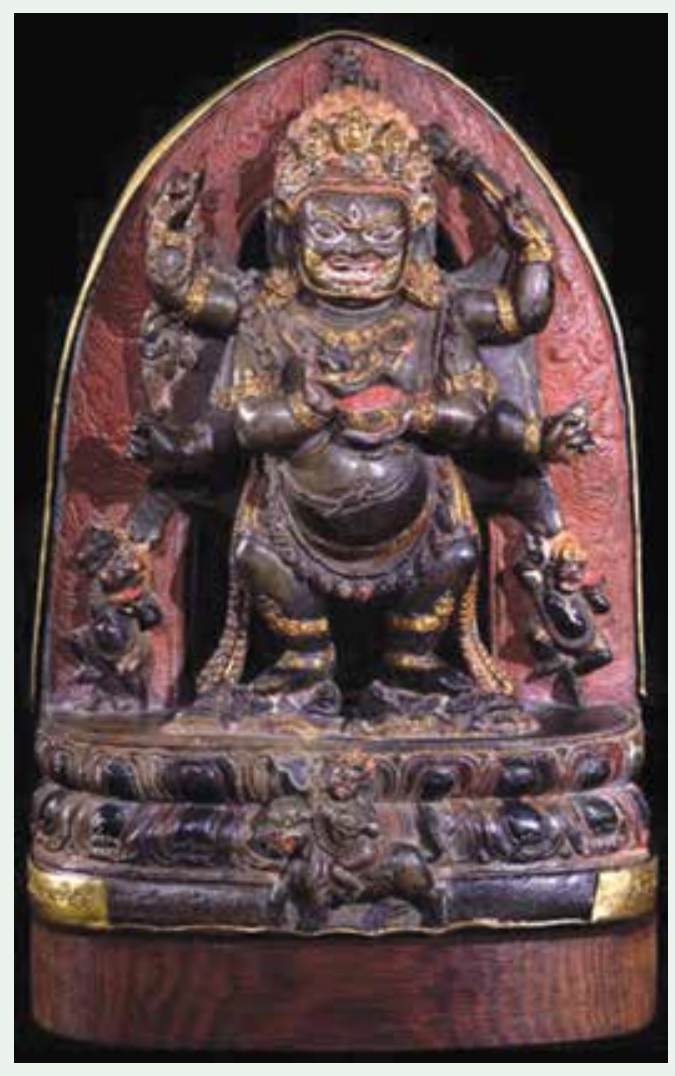

Shadbhuja Mahākāla

the different traditions principally the leg postures of Mahākāla, the Gelugpa preferring the more wrathful posture with the legs apart. The Tsarpa lineage of Sakya prefers Shri Devi with four hands so as not to confuse her with Magzor Gyalmo the younger sister or servant that has two hands. The colours and hand objects of the remaining retinue also vary according to individual traditions.

(Eight-Chapter Mahākāla Tantra)

Iconography: "The Lord of Pristine Awareness has six hands and a body dark blue in color. The first two hold 
a curved knife and skull cup, the middle two a human skull mālā and trident, the lowest two a damaru drum and lasso.

Shadbhuja Mahākāla is adorned with a tiger skin, garland of heads, bones and snakes, and small bells on the hands and feet. He has three eyes, bared fangs, eyebrows, beard and hair flowing upward with Akshobhya as a crown. He is anointed with a sindhura drop on the forehead. And behind him is a sandalwood tree, dwelling in the middle of a blazing mass of fire. (Jonang Taranatha, 1575-1634).

Danda Mahākāla (Tibetan: gon po beng leg den nag po sri me gyi bu): a main wisdom protector of the Nyingma School

Wrathful, black in color, with one face and two hands, he holds upraised in the right a sandalwood staff and a skull cup held to the heart in the left. Wearing a long black cloak he stands atop a corpse seat, sun disc and lotus blossom, surrounded by the flames of wisdom.

At the top center is the Bodhisattva Avalokiteshvara accompanied by various figures along with Padmasambhava. At the bottom left is the worldly protector Damchen Garwa'i Nagpo along with others in the middle and on the right. (Jeff Watt 9-2000)

\section{Kartaridhara Mahākāla}

Kartaridhara is wrathful in appearance, dark in colour, with one face and two hands. He holds upraised in the right a curved knife (kartāri). In the left he holds a skullcup to the heart. Kartaridhara can be found in the Nartang Gyatsa publication. There are several traditions of practice. The famous is that of Jowo Atisha.

According to the Panjarnata system of Mahākāla there are two forms of the deity that have the same appearance as Kartāridhara. The first form is 'Copper Knife' Mahākāla associated with the Eight Deity practices of Panjarnata Mahākāla. The second is associated with the Seventeen Deity Panjarnata Mandala. (Jeff Watt 8-2017)

Brahmarupa Mahākāla (Tibetan: gon po dram ze. English: the Mahākāla who appears in the form of a Brahman). Sanskrit: Brahmarupa Tibetan: Dram ze

Appearing as an Indian Brahman, dark brown in colour, he has one face and two hands. With the right hand he holds a human shin-bone trumpet and in the left, upraised, a human skull filled with blood. The hair, beard and eyebrows are white. Wearing bone ornaments, intestines and a human skin he sits atop a human body.

At the edges of the pristine awareness wisdom fire are four dakinis, ghoulish in appearance, dynamic in posture, Dombini, Chandali, Rakshasi and Singhali Devi - black, red, yellow and green. They are naked with 


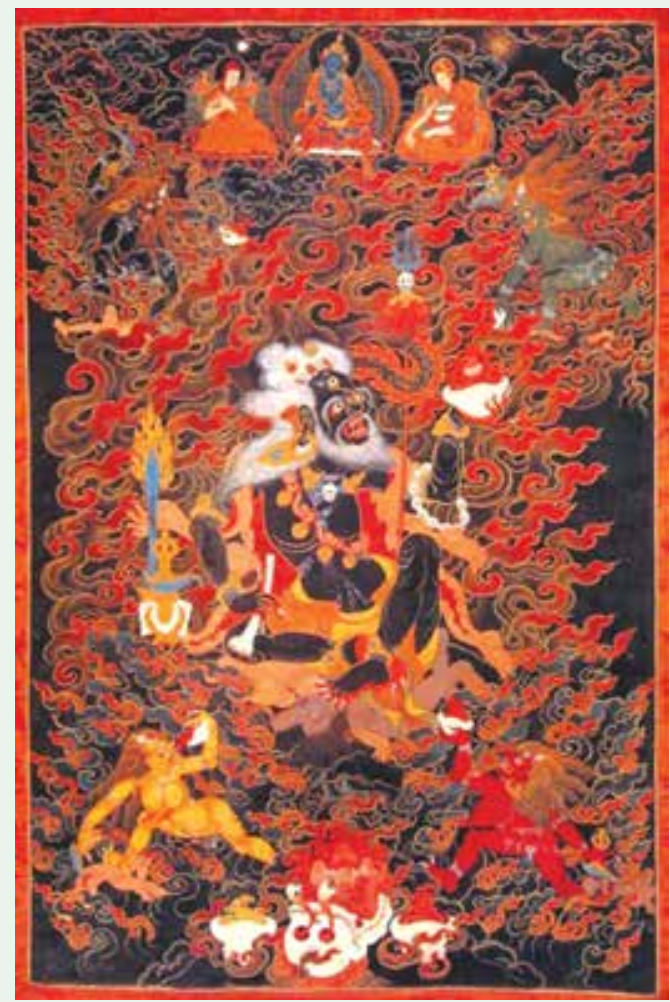

Brahmarupa Mahākāla

disheveled orange hair, each holding a curved knife and a skull cup.

The Legend: When the great Tibetan Translator Nyen Lotsawa received the Manjuvajra Guhyasamaja (also known as the Jnanapada Lineage) empowerment from the dakini Risula, she also bestowed the initiation of the Mahākāla (Chaturmukha) in the special form according to the Guhyasamāja Tantra.

At this time she gave him as a servant a dark skinned Brahman. When Nyen Lotsawa and the Brahman reached Nepal the servant changed appearance and took on the form of a monk, an appearance more conducive for travelling in Tibet. After the passing of Nyen Lotsawa the monk remained with Lama Nam Ka'upa and then later with Sachen Kunga Nyingpo. (Jeff Watt 8-2005)

The objective of Mahākāla practice is to assist practitioners in removing any challenges that impedes their spiritual practice, as well as to encourage exertion and devotion and at the same time purify obscuration and defilements. With earnest prayer and diligent practices, blessings will be bestowed and obstacles will be pacified.

The Buddhist claim that Mahākāla is the protector of Dharma and religious law

\section{Reference}

Bhagavad Gita 11.32.

Brahma Purana, section Shiva Mahākāla.

Chaturvedi, B. K. (2006). Shiv Purana (First ed.), New Delhi: Diamond Pocket Books (P) Ltd, ISBN 81-7182-721-7.

Emi, Matsushita. Iconography of Mahākāla. MA Thesis, The Ohio State University, 2001. Link of full-length Thesis http:// rave.ohiolink.edu/etdc/view?acc_ num $=$ osu1141933891

Kalsang, Ladrang (1996). The Guardian Deities of Tibet, Delhi: Winsome Books. (Third Reprint 2003) ISBN 81-88043-04-4.

Kinsley, David R. (1997). Tantric visions of the divine feminine: the ten mahāvidyās. University of California Press. ISBN 978-0520-20499-7.

Himalayan Art Resource, www.Mahākāla. com 
Lorenz, Ekkehard (2007). The Harivamsa: The Dynasty of Krishna, in Edwin F. Bryant (ed.), Krishna, A Source Book, Oxford University Press.

Linrothe, Rob (1999). Ruthless Compassion: Wrathful Deities in Early Indo-Tibetan Esoteric Buddhist Art, London: Serindia Publications. ISBN 0-906026-51-2.

Max Muller. Shvetashvatara Upanishad, The Upanishads, Part II, Oxford University Press, p 250

Maithily, Jagannathan. Published 2005, Abhinav Publications, ISBN 81-7017-415-5.

Mookerjee, Ajit (1988). Kāli: The Feminine Force. New York: Destin Parashara M. Brihat.

Parasara, Hora Sastra. Guide to Hindu Astrology. In: Sharma GC, editor. New Delhi: Sagar; 1994.

Robert, Hume (1921). Shvetashvatara Upanishad, The Thirteen Principal Upanishads. Oxford University Press, pages 402-406.

Shaktisamgama Tantra, Kāli Khanda.

Sir John George, Woodroffe. Shakti and Shâkta: Essays and Addresses on the Shâkta Tantrashâstra. Ganesh, 1951, ISBN $160620145 X, 9781606201459$.

William, Stablein. The Mahākālatantra: A Theory of Ritural Blessings and Tantric Medicine. Ph.D. Dissertation, Columbia University, 1976.

www.shivashakti.com Mahākāla.htm

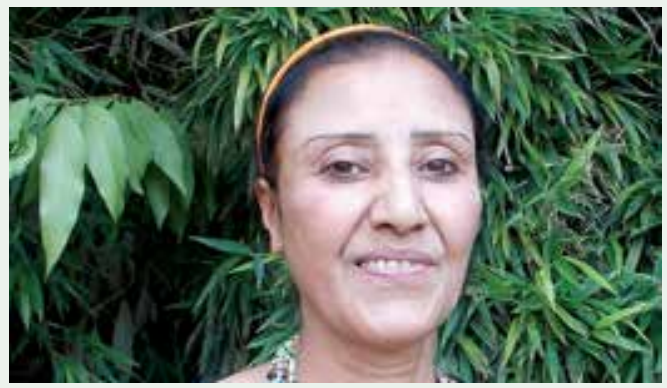

\section{Dr. Poonam Rajya Laxmi Rana}

Dr. Poonam Rajya Laxmi Rana is an Associate Professor in the Department of Nepalese History Culture and Archaeology, Tribhuvan University, Kirtipur, Kathmandu, Nepal.

She holds Masters Degree in Sociology and Environment and Ecology and Doctorate in Nepalese History Culture and Archaeology.

She has participated in various National and International Seminars and Conferences. 